\title{
MARKET OF MINERAL WATER IN UKRAINE: PROBLEMS OF QUALITY AND SAFETY
}

\author{
A. Zainchkovskiy, A. Kushnirenko \\ National University of Food Technologies
}

\begin{tabular}{l}
\multicolumn{1}{c}{ Key words: } \\
Bottled drinking water \\
Safety \\
Level of pollution \\
Water quality \\
\hline \multicolumn{1}{c}{ Article history: } \\
Received 19.07.2018 \\
Received in revised form \\
01.08.2018 \\
Accepted 20.08.2018 \\
\hline
\end{tabular}

Corresponding author:
A. Kushnirenko
E-mail:
anya4000@i.ua

\begin{abstract}
The following paper reviews the current state of the market and presents the results of reseach quality and safety of natural mineral bottled water.

The quality and safety assessment of mineral being sold in the Ukrainian market is water performed using parameters of labelling and packaging compliance for test samples of therapeutic-table water. That is, the study object was mineral water extracted from underground wells and bottled with subsequent sale through the retail trade network of Ukraine, packaged in a consumer PET bottle with a capacity of 1.5 liters - from five manufacturers. Comprehensive analysis of organoleptic and physico-chemical parameters has been carried out that allowed determining the hydrogen value $(\mathrm{pH})$ and iron content of the selected mineral water samples. Methods were used of statistical and comparative analysis of the Ukrainian mineral water trademarks, which evaluated the qualitative composition of water.
\end{abstract}

The economic situation in Ukraine affected the market of packaged natural mineral water. Despite the fact that almost all water supply companies operate within the country and extract water in Ukraine, production and supply costs for 2016-2017 increased substantially. The study showed that the exchange rate affected the cost of consumables, fuel and lubricants, components, and transportation. Accordingly, the production cost for consumer increased significantly (by about $25-40 \%$ depending on the region and supplier). Still water consumption is increasing due to increased demand for water on tap and in large containers being ordered with a delivery to home or office. The obtained forecasts indicate that the mineral water supply market will increase with a further tendency to increased still mineral water consumption.

The used methods of statistical and comparative analysis to trade marks of mineral water of Ukraine, that they which were able to assess the quality of water. The proposals to guarantee the safety of packaged natural mineral water, which is realized in retail chains in Ukraine.

DOI: $10.24263 / 2225-2924-2018-24-4-14$ 


\title{
РИНОК МІНЕРАЛЬНОÏ ВОДИ В УКРАÏНI: ПРОБЛЕМИ ЯКОСТІ ТА БЕЗПЕКИ
}

\author{
А.О. Заїнчковський, А.М. Кушніренко \\ Національний університет харчових технолоігій
}

У статті розглянуто сучасний стан ринку, наведено результати досліджень якості та безпечності мінеральної природної води. Проведено очінювання якості та безпечності мінеральної води, щзо реалізується на ринку України, за допомогою показників відповідності маркування та пакування дослідних зразків лікувально-столових мінеральних вод. Об 'єктом дослідження була мінеральна вода, щзо видобувається з підземних свердловин та розливається у пляшки і реалізується у роздрібній торговельній мережі Украӥни. Вода упакована в споживчу тару ПЕТ-пляшку місткістю 1,5 літра. Здійснено комплексний аналіз органолептичних $i$ фізико-хімічних показників, щуо дали змогу встановити рівень водневого показника $(\mathrm{pH})$ та вміст заліза вибраних зразків мінеральної води. Використано методи статистичного та порівняльного аналізу торговельних марок мінеральних вод України для оџінки якісного складу води.

Проаналізовану економічну ситуачію в Украӥні, яка вплинула на ринок мінеральної природної фасованої води. Визначено, щзо майже всі компанії, які здійснюють доставку води, ведуть свою діяльність у межах країни і добувають воду також в Украӥні, збільиили витрати на виробництво і доставку води у 2016-2017 роках. У прочесі дослідження виявлено, щуо курс валют вплинув як на вартість витратних і паливно-мастильних матеріалів, комплектуючих, так і на витрати з транпортування. Відповідно, вартість продукиії для споживача значно збільшилась (приблизно на 25-40\% залежно від регіону та постачальника). 3'ясовано, щчо спожсвання негазованої води зростає за рахунок збільшення попиту на розлив води у велику тару на замовлення до будинку чи офісу. Отримані прогнози свідчать, щзо ринок пропозиції мінеральних вод буде зростати та збережеться подальша тенденція до збільшення споживання негазованої мінеральної води.

Надано пропозиції щодо гарантування безпечності мінеральної природної води, яка реалізується у роздрібних торговельних мережах Украӥни.

Ключові слова: стан ринку, мінеральна питна вода, безпечність, рівень забруднення, якість води.

Problem statement. The problem of quality and safety of drinking water is becoming a global issue. The modern world has become even more pretentious to the consumer properties of water in connection with the detection of chronic diseases and intoxication of people through consumption of poor-quality and dangerous drinking water [3]. According to the monitoring carried out in Ukraine, the problem of guaranteeing the mineral water safety is very acute. According to experts, more than $65 \%$ of Ukrainians use water that is unsuitable for consumption. The main causes for this phenomenon is that the rivers of Ukraine are of the $3^{\text {rd }}$ and 
$4^{\text {th }}$ degree of pollution; imbalance in the location scheme of the most water-based enterprises, imperfect water policy and legislation on safety and quality of drinking water [2].

Mineral water is considered to be underground (sometimes superficial) water with high content of some chemical elements and compounds, as well as gases with specific physical and chemical properties (temperature, radioactivity, etc.) that have a healing effect on the human body. Mineralization defines the difference between the fresh and mineral water. Mineral water often has healing properties and are used for medicinal purposes, as well as bottled in sealed packaging at the enterprises for sale through wholesale and retail networks to the population.

The amount of mineral water bottling increases every year by $15-20 \%$, but the issue of guaranteeing mineral water safety and quality remains extremely relevant. Relevant issues with regard to providing natural mineral water include the prevalence of shallow steppe and forest-steppe zones; limited water resources of own formation ( $50 \mathrm{billion} \mathrm{m}^{3} /$ year), including 21 billion $\mathrm{m}^{3} /$ year of groundwater with drinking quality [11].

Analysis of recent research and publications. The global issue of providing high quality drinking water to the population is under continuous study by Ukrainian and foreign scientists: V.O. Prokopov, O.B. Lypovetska, O.V. Zorina, O.V. Shushkovska, O. A. Dmitrieva, O. M. Kuzminets, V. A. Sobol, G. M. Semchuk, T. Boonyakarnkul, D. Cunliffe, W. Grabow, A. Havelaar, M. Sobsey.

The overwhelming majority of scientific research is aimed at addressing the issue of water purification.

At the same time, additional complex research is required to address the issue of mineral water safety in consumer packaging within a specified shelf life.

Purpose of the paper is to assess the quality and safety of mineral water being sold in the Ukrainian market.

To achieve this goal, the following tasks were performed:

- mineral water analysis;

- factors of formation and preservation of consumer properties of natural mineral water;

- comparative estimation of the quality of mineral water from different producers;

- mineral water safety parameters identified in different manufacturers;

- methods identified to improve quality and guarantee mineral water safety. The object of the study was mineral water, extracted from underground wells, bottled, and sold through the retail trade network of Ukraine, packed in a consumer PET bottle with a capacity of 1.51 from the following manufacturers:

- TM Luzhanska (PE “Alex”);

- TM Morshynska (PJSC “Morshyn Plant of Mineral Water "Oscar”);

- TM Poliana Kvasova (Svaliava Mineral Water);

- TM Truskavetska (LLC “AQUA-ECO”);

- TM Ploskivska (Ploskovsky Mineral Water Plant).

The subject of the study - consumer properties of mineral water being sold through the retail trade network of Ukraine. 
Statement of basic materials. The study of consumer preferences in the market of packaged mineral water showed that consumers have confidence in the popular trademarks. Thus, 10 large producers own almost $50 \%$ of the entire mineral water market and almost $70 \%$ of still water market; small trademarks and local producers, own $50 \%$ of the mineral water market and $30 \%$ of still water market, respectively [8].

Major producers of mineral water in Ukraine:

- PJSC "IDS Borjomi Ukraine" (Myrhorodska, Myrhorodska Lahidna, AquaLife, Old Myrhorod, Morshynska, Sorochynska, Truskavetska, Borjomi);

- Private Enterprise "Alex" (Luzhanska, Shaianska, Poliana Sribna, Poliana Svitla, Poliana Kupel-5, Poliana Kvasova-8).

Studies showed that the mineral water market has a tendency to decrease consumption of strongly sparkling mineral water and increase of consumption of medium sparkling and still mineral water. In 2016, the share of still water was $37 \%$, which is $12 \%$ more than in 2017 . The consumption of still water is increasing due to increased demand for on tap water and water in large containers delivered to home or office at request.

The economic situation in Ukraine has affected the market of natural mineral packaged water. Despite the fact that almost all water supply companies operate within the country and produce water in Ukraine, production and supply costs for 2016-2017 have increased substantially. This is due both to the exchange rate, which affected the cost of consumables (label, cap, dust cap, container), fuel and lubricants, components, and increase in tariffs for water intake and utilities. Accordingly, the production cost for consumer in comparison with January 2017 also increased (approximately by $25-40 \%$ depending on the region and supplier).

It should be noted that during 2012-2017, the sales volume in the mineral water market increased by an average of $6-8 \%$ per year. The largest demand for mineral water was observed during the period from May to September. However, the consumption culture for bottled water in Ukraine remains low. The average Ukrainian consumes about 40 litres of water per year, while a resident of neighbouring Poland consumes more than 70 litres, the Czech Republic - more than 90 litres. Analysts predict that the market for mineral water supply will grow and a further trend to increase in still water consumption will be preserved.

The main market indicators include production, export, import and market capacity (possible sales volume).

Table 1. considers the main market indicators for mineral water (in kind). Market capacity over the last 4 years has shown a negative dynamics. The reduction rate in 2014 was 5\%; within the next two years this figure fell by another $9 \%$ and $5 \%$. The reason for this trend was the decrease in the production volume of mineral water and decreased imports. During the research period, Ukrainian companies managed to increase the supply of mineral water abroad. Exports in 2016 increased 1.4-fold compared to this index in 2013. According to 1Q2017 results (compared to the same period in 2016), despite the insignificant macroeconomic stabilization in the country, the market capacity has shown an increase of $7 \%$. Supplies of domestic products abroad, as well as imports, as shown in Table 1, contributed to this increase in the production volume of mineral water. 1. 
Table 1. General market indicators of mineral water in Ukraine for 2013-1Q 2017*, in volume terms, USD ths

\begin{tabular}{|c|c|c|c|c|c|c|}
\hline Indicators & 2013 & 2014 & 2015 & 2016 & $1 \mathrm{Q} 2016$ & $1 \mathrm{Q} 2017$ \\
\hline Production & 85182,0 & 81140,2 & 75621,0 & 71762,3 & 13039,2 & 13747,5 \\
\hline Export & 430,4 & 358,5 & 433,1 & 582,5 & 96,0 & 133,7 \\
\hline Import & 6159,3 & 5689,5 & 3468,6 & 3848,5 & 624,9 & 870,6 \\
\hline Market capacity & 90911,0 & 86471,1 & 78656,5 & 75028,3 & 13568,1 & 14484,4 \\
\hline Growth rate, \% & & $-5 \%$ & $-9 \%$ & $-5 \%$ & & $7 \%$ \\
\hline
\end{tabular}

* Hereinafter the data for 2014 are given without taking into account the Crimea and the city of Sevastopol, from 2015 to 2017 — without taking into account the Autonomous Republic of Crimea, the city of Sevastopol and ATO Zone.

Source: State Statistics Service of Ukraine.

In monetary terms, the market of mineral water demonstrates the opposite dynamics. Market capacity in 2014 increased almost 2-fold compared to 2013. This situation arose as a result of rapid UAH devaluation and high inflation rates against the background of political crisis in 2014. In 2015, the growth rate of this indicator slowed decrease and amounted to $24 \%$. Last year the market increased by $3 \%$. The first quarter of this year, as compared to the same period in 2016, is also characterized by an increase in all indicators. The market capacity has shown a growth of $29 \%$. This is justified by the fact that the trajectory of the exchange rate has become similar to last year - a jump, then return to a lower level.

The volumes of mineral water import are increasing each year: 2010 imports increased by almost $40 \%, 2015$ - by $21 \%$. Georgia is the main supplier of mineral water in Ukraine. Other suppliers include Russia, France, Italy, Poland. Canada, Switzerland [7].

Mineral water market monitoring indicates an increase in segment proportion of natural therapeutic mineral water packed in a container with a capacity of 0.5 1.5 litres and an increase in the consumption of medium sparkling water in the mineral water segment. Thus, in 2017, the segment of packed drinking water showed an increase in share of water packed in containers of $0.5-1.5$ litres to $25 \%$, while in 2014 this figure was $20.2 \%$. The share of medium sparkling water in the mineral water segment is $10 \%$, while in 2014 it was only $5 \%$. The largest consumption of packaged water in 2017 per capita was observed in the cities of Ukraine $(10.6 \mathrm{~L})$. The leader is Odesa $(13.6 \mathrm{~L})$, second place - Kyiv (11.7 L). The lowest index was reported in the regions $(8.6 \mathrm{~L})$.

Accordingly, the potential of the mineral water market is high enough, provided the guaranteed level of quality and safety.

Mineral drinking water intended for human consumption for therapeutic and prophylactic purposes is the water, the composition of which according to organoleptic, physico-chemical, microbiological, parasitic and radiation indicators meets the requirements of state standards and sanitary legislation (extraction is carried out from underground or ground deposits — pump rooms, bottling points, mine wells and catchments of springs), intended to provide physiological, sanitary, hygienic, household and economic needs of the population, as well as for the manufacture of products requiring the mineral water use [4]. 
Each unit of consumer packaging with mineral water is labelled in accordance with the current regulatory documents. Mineral water is bottled directly near the place of extraction under compliance with sanitary requirements. Labelling and packaging analysis of the experimental samples of mineral natural table water is given (in Table. 2).

Table 2. Analysis of labelling and packaging conformity of natural mineral water

\begin{tabular}{|c|c|c|c|c|c|}
\hline Indicators & $\begin{array}{c}\text { TM } \\
\text { Luzhanska }\end{array}$ & $\begin{array}{c}\text { TM } \\
\text { Morshynska }\end{array}$ & $\begin{array}{c}\text { TM } \\
\text { Poliana } \\
\text { Kvasova } \\
\end{array}$ & $\begin{array}{c}\text { TM } \\
\text { Truskavetska }\end{array}$ & $\begin{array}{c}\text { TM } \\
\text { Ploskivska }\end{array}$ \\
\hline $\begin{array}{l}\text { Name, full address } \\
\text { and phone number } \\
\text { of manufacturer, } \\
\text { production site } \\
\text { address } \\
\text { production }\end{array}$ & + & + & + & + & + \\
\hline $\begin{array}{c}\text { Location } \\
\text { and extraction well } \\
\text { number }\end{array}$ & + & + & + & + & - \\
\hline $\begin{array}{c}\text { Mineralization, } \\
\mathrm{g} / \mathrm{dm}^{3}\end{array}$ & $2,7-4,8$ & $0,1-0,4$ & $6,5-12,0$ & $0,25-0,9$ & $3,5-7,5$ \\
\hline $\begin{array}{l}\text { Chemical } \\
\text { composition }\end{array}$ & + & + & + & + & + \\
\hline $\begin{array}{l}\text { Water condition by } \\
\text { degree of saturation } \\
\text { with dioxin carbon }\end{array}$ & $\begin{array}{l}\text { Strongly } \\
\text { sparkling }\end{array}$ & Mineral & Mineral & Mineral & $\begin{array}{l}\text { Strongly } \\
\text { sparkling }\end{array}$ \\
\hline Origin & $\begin{array}{c}\text { Mineral } \\
\text { natural }\end{array}$ & $\begin{array}{c}\text { Mineral } \\
\text { natural }\end{array}$ & $\begin{array}{c}\text { Mineral } \\
\text { natural }\end{array}$ & Mineral natural & $\begin{array}{c}\text { Mineral } \\
\text { natural }\end{array}$ \\
\hline Water use & $\begin{array}{l}\text { Therapeutic } \\
\text { table water }\end{array}$ & Table water & $\begin{array}{l}\text { Therapeutic } \\
\text { table water }\end{array}$ & Table water & $\begin{array}{l}\text { Therapeutic } \\
\text { table water }\end{array}$ \\
\hline $\begin{array}{l}\text { Recommendations } \\
\text { for therapeutic use }\end{array}$ & 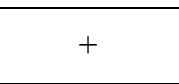 & - & 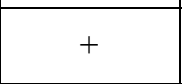 & - & . \\
\hline Main contradictions & - & - & - & - & - \\
\hline $\begin{array}{l}\text { Designation of } \\
\text { regulatory } \\
\text { documents }\end{array}$ & $\begin{array}{l}\text { DSTU 878- } \\
93\end{array}$ & DSTU 878-93 & $\begin{array}{c}\text { DSTU 878- } \\
93\end{array}$ & DSTU 878-93 & DSTU 878-93 \\
\hline $\begin{array}{c}\text { Consumption end } \\
\text { date }\end{array}$ & + & + & + & + & + \\
\hline Batch number & + & + & + & + & + \\
\hline Storage conditions & + & + & + & + & + \\
\hline $\begin{array}{l}\text { Consumer } \\
\text { packaging }\end{array}$ & $\begin{array}{c}\text { PET } \\
\text { container }\end{array}$ & PET container & $\begin{array}{c}\text { PET } \\
\text { container }\end{array}$ & PET container & PET container \\
\hline Capacity, 1 & 1,5 & 1,5 & 1,5 & 1,5 & 1,5 \\
\hline $\begin{array}{l}\text { Tightness of } \\
\text { packing }\end{array}$ & + & + & + & + & + \\
\hline
\end{tabular}

During analysis of labelling and packaging conformity of still and mineral packaged water, it was found that there is no indication of the well number on the mineral water label of Ploskivska TM, which confirms the necessity of harmonization of the domestic legislation with respect to the labelling rules. Reco- 
mmendations for therapeutic use are indicated in Luzhanska TM, Poliana Kvasova TM, Ploskivska TM, contraindications are common for therapeutic water, and corresponding designations are for some reason missing on the label. Consequently, the indicators of labelling and packaging of mineral and still water samples do not comply with the requirements of the Technical Regulation on Rules for labelling food products and pp. 8, 9 DSTU 878-2006 "Mineral drinking Water. Specifications".

Identification of organoleptic parameters of the packed water quality was carried out in accordance with DsanPin 2.2.4-171-10 "Hygienic requirements to drinking water for human consumption" [2].

To assess the quality of drinking mineral water, we have developed a 5-point scale for assessing the mineral water quality (Table. 3 ).

Table 3. Organoleptic evaluation of drinking water quality

\begin{tabular}{|c|c|c|c|c|c|c|}
\hline Indicator & $\begin{array}{c}\text { Description } \\
\text { according to RD }\end{array}$ & $\begin{array}{c}\text { TM } \\
\text { Luzhanska }\end{array}$ & \begin{tabular}{|c|} 
TM \\
Morshynska
\end{tabular} & \begin{tabular}{|c|} 
TM Poliana \\
Kvasova
\end{tabular} & $\begin{array}{c}\text { TMTruskav } \\
\text { etska }\end{array}$ & $\begin{array}{c}\text { TM } \\
\text { Ploskivska }\end{array}$ \\
\hline Appearance & $\begin{array}{l}\text { Very pleasant, } \\
\text { typical of } \\
\text { drinking water }\end{array}$ & $\begin{array}{c}\text { Very } \\
\text { pleasant, } \\
\text { typical of } \\
\text { drinking } \\
\text { water }\end{array}$ & $\begin{array}{l}\text { Pleasant, } \\
\text { typical of } \\
\text { drinking } \\
\text { water }\end{array}$ & $\begin{array}{l}\text { Pleasant, } \\
\text { typical of } \\
\text { drinking } \\
\text { water }\end{array}$ & $\begin{array}{l}\text { Pleasant, } \\
\text { typical of } \\
\text { drinking } \\
\text { water }\end{array}$ & $\begin{array}{l}\text { Pleasant, } \\
\text { typical of } \\
\text { drinking } \\
\text { water }\end{array}$ \\
\hline \multicolumn{2}{|r|}{ Score } & 4,9 & 4,6 & 4,7 & 4,5 & 4,3 \\
\hline Clarity & High & High & High & High & High & High \\
\hline \multicolumn{2}{|r|}{ Score } & 4,9 & 4,8 & 4,8 & 4,8 & 4,7 \\
\hline Flavour & $\begin{array}{c}\text { Very pleasant, } \\
\text { typical of } \\
\text { drinking water } \\
\text { without a foreign } \\
\text { flavour }\end{array}$ & $\begin{array}{c}\text { Very } \\
\text { Pleasant, } \\
\text { typical of } \\
\text { drinking } \\
\text { water } \\
\text { without a } \\
\text { foreign } \\
\text { flavour }\end{array}$ & $\begin{array}{l}\text { Pleasant, } \\
\text { typical of } \\
\text { drinking } \\
\text { water, with } \\
\text { a slight } \\
\text { flavour }\end{array}$ & $\begin{array}{c}\text { Pleasant, } \\
\text { typical of } \\
\text { drinking } \\
\text { water, with a } \\
\text { slight flavour }\end{array}$ & $\begin{array}{c}\text { Pleasant, } \\
\text { typical of } \\
\text { drinking } \\
\text { water, with } \\
\text { a slight } \\
\text { flavour }\end{array}$ & $\begin{array}{l}\text { Pleasant, } \\
\text { typical of } \\
\text { drinking } \\
\text { water, with a } \\
\text { slight flavour }\end{array}$ \\
\hline \multicolumn{2}{|r|}{ Score } & 4,9 & 4,3 & 4,5 & 4,0 & 3,8 \\
\hline Odour & $\begin{array}{c}\text { Very pleasant, } \\
\text { typical of } \\
\text { drinking water } \\
\text { without a foreign } \\
\text { odour }\end{array}$ & $\begin{array}{c}\text { Very } \\
\text { pleasant, } \\
\text { typical of } \\
\text { drinking } \\
\text { water } \\
\text { without a } \\
\text { foreign } \\
\text { odour }\end{array}$ & $\begin{array}{l}\text { Pleasant, } \\
\text { typical of } \\
\text { drinking } \\
\text { water } \\
\text { without a } \\
\text { foreign } \\
\text { odour }\end{array}$ & $\begin{array}{l}\text { Pleasant, } \\
\text { typical of } \\
\text { drinking } \\
\text { water } \\
\text { without a } \\
\text { foreign } \\
\text { odour }\end{array}$ & $\begin{array}{l}\text { Pleasant, } \\
\text { typical of } \\
\text { drinking } \\
\text { water } \\
\text { without a } \\
\text { foreign } \\
\text { odour }\end{array}$ & $\begin{array}{l}\text { Pleasant, } \\
\text { typical of } \\
\text { drinking } \\
\text { water without } \\
\text { a foreign } \\
\text { odour }\end{array}$ \\
\hline \multicolumn{2}{|r|}{ Score } & 4,8 & 4,5 & 4,3 & 4,5 & 4,5 \\
\hline Colour & Clear, typical & $\begin{array}{l}\text { Clear, } \\
\text { typical }\end{array}$ & $\begin{array}{l}\text { Clear, with } \\
\text { a slight } \\
\text { colour }\end{array}$ & $\begin{array}{l}\text { Clear, with a } \\
\text { slight colour }\end{array}$ & $\begin{array}{c}\text { Clear, with } \\
\text { a slight } \\
\text { colour }\end{array}$ & $\begin{array}{l}\text { Clear, with a } \\
\text { slight colour }\end{array}$ \\
\hline \multicolumn{2}{|c|}{ Score } & 4,9 & 4,4 & 4,7 & 4,4 & 4,5 \\
\hline \multicolumn{2}{|c|}{ Total score } & 24,4 & 22,6 & 23,0 & 22,2 & 21,8 \\
\hline
\end{tabular}

According to the results of the organoleptic evaluation, the highest score was received with the sample of packaged drinking water TM Luzhanska due to high 
scores for all indicators. The lowest score in organoleptic evaluation was given to TM Ploskivska due to the low flavour score.

Objective assessment involves a comprehensive combination of organoleptic and physico-chemical indicators. The following quality and safety indicators of drinking mineral water were determined by physical and chemical methods:

- hydrogen value $(\mathrm{pH})$;

- iron content (III).

Hydrogen value $(\mathrm{pH})$ is one of the most important indicators of water quality, which determines the nature and rate of the chemical and biological processes, indicates the degree of acidity or alkalinity of water. At neutral $\mathrm{pH}$ (7.0), acids and alkalis are present in water in equal quantities (or absent at all). This medium is the most balanced and optimal for biochemical reactions in the body. At the same time, water with a reduced $\mathrm{pH}$ has increased corrosion activity, and with increased $\mathrm{pH}$ it has a characteristic medium alkalinity, causes offensive odour, eyes and skin irritation. Natural $\mathrm{pH}$ is usually within the limits, where it does not directly affect the consumer water quality.

Results for hydrogen value of mineral water, that characterizes the acidity of medium, are given in Table 4.

Table 4. Hydrogen value of mineral water

\begin{tabular}{|c|c|c|c|c|c|}
\hline & TM Luzhanska & TM Morshynska & $\begin{array}{c}\text { TM Poliana } \\
\text { Kvasova }\end{array}$ & $\begin{array}{c}\text { TM } \\
\text { Truskavetska }\end{array}$ & TM Ploskivska \\
\hline $\mathrm{pH}$ & 7.5 & 6.4 & 7.8 & 7.23 & 7.9 \\
\hline
\end{tabular}

Thus, the hydrogen value of the packaged water samples was characterized by the following indicators: mineral water TM Luzhanska - 7.5, mineral water TM Morshynska - 6.4, mineral water TM Poliana Kvasova - 7.8, mineral water TM Truskavetska - 7.23, mineral water TM Ploskivska - 7.9.

According to DSanPin 2.2.4-171-10 "Hygienic requirements to drinking water for human consumption", the hydrogen value of still and mineral water should be from $\mathrm{pH} 6.5$ to 8.5 . The only sample that does not meet standard requirements is

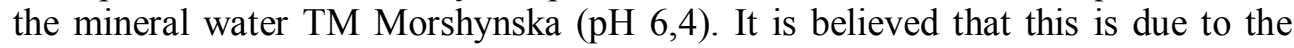
fact that carbon dioxide dissolves in water during air contact, from which the carbonic acid $\mathrm{H}_{2} \mathrm{CO}_{3}$ is formed; this results in decreased water $\mathrm{pH}$ up to 5.7-6. This causes a slight sour taste, which worsens the organoleptic properties of water.

In addition to acidity level, iron content (III) was evaluated, which is one of the most common natural elements. The superficial sources water usually contains iron in the form of organic compounds, mainly colloidal (insoluble in water). Iron (III) can create conditions for bacterial iron development. As a result, the water supply systems can be "overgrown" completely in a few months. The water containing iron can have a rainbow film on the surface and create an iron precipitate on pipes of the water supply systems. In addition to the natural content of iron (II) and iron (III), it is added metal surfaces corrosion in water. Long-term human use of water with an iron content of more than $0.2 \mathrm{mg} / \mathrm{l}$ leads to liver disease, increased risk of heart attack, and the like. With high iron concentrations water develops a characteristic metallic flavor, which negatively affects the taste of beverages [5]. 
The results of iron content (III) identification in drinking water, which characterizes the level of pollution and water safety, are given in Table 5.

Table 5. Iron content (III) in drinking mineral water

\begin{tabular}{|c|c|c|c|c|c|}
\hline & TM Luzhanska & TM Morshynska & $\begin{array}{c}\text { TM Poliana } \\
\text { Kvasova }\end{array}$ & $\begin{array}{c}\text { TM } \\
\text { Truskavetska }\end{array}$ & TM Ploskivska \\
\hline $\mathrm{mg} / \mathrm{l}$ & 0.0000 & 0.0021 & 0.0021 & 0.0021 & 0.0041 \\
\hline
\end{tabular}

Consequently, the iron content (III) in still packaged water was characterized by the following values: mineral water TM Luzhanska $-0.0000 \mathrm{mg} / \mathrm{l}$, mineral water TM Morshynska - $0.0021 \mathrm{mg} / \mathrm{l}$, mineral water TM Poliana Kvasova $0.0021 \mathrm{mg} / \mathrm{l}$, mineral water TM Truskavetska $-0.0021 \mathrm{mg} / \mathrm{l}$, mineral water TM Ploskivska $-0.0041 \mathrm{mg} / \mathrm{l}$. According to DSanPin 2.2.4-171-10 "Hygienic requirements to drinking water for human consumption" the maximum permissible iron content in still packaged water shall not exceed $0.2 \mathrm{mg} / \mathrm{l}$. Consequently, we can conclude that the iron content in still packaged water samples meets the requirements of DSanPin 2.2.4-171-10 "Hygienic requirements to drinking water for human consumption" [4].

\section{Conclusions and proposals}

Thus, based on results of organoleptic and physico-chemical studies of still packaged mineral water samples, we can conclude:

- Studied mineral water samples have a good level of organoleptic properties;

- Mineral water TM Morshynska does not meet the requirements of DSanPin 2.2.4-171-10 "Hygienic requirements to drinking water for human consumption" relative to the hydrogen value $(\mathrm{pH} 6,4)$, which is explained by the probable violation of production process due to excessive water-air contact;

- Studied samples have a very low iron content (III), meet the requirements of DSamPin 2.2.4-171-10 "Hygienic requirements to drinking water for human consumption" and are safe for consumption.

In order to ensure the guaranteed level of the mineral water quality and safety, we offer:

1. To ensure proper financing of the National Target Program "Mineral Water of Ukraine" for 2018-2026.

2. To implement the "Procedure for state registration of artesian wells..." (Resolution No. 963 of the Cabinet of Ministers of Ukraine dated 08.10.2012) and finalize the Code of Ukraine "On Subsoil" in the area of drinking groundwater extraction for own household and economic needs without obtaining special permits and mining lease;

3. To introduce ecological and economic methods of water management.

4. To introduce accelerated monitoring of surface and underground water facilities (ground, Earth remote sensing, and permanent models).

We believe that these measures will contribute to the improvement of mineral water quality and safety, and will be assimilated among the population for treatment and healing purposes. 


\section{References}

1. GOST 4011-72 (1974). Drinking water. Methods for measuring the mass concentration of total iron, Publishing house of standards, M., P.8.

2. GOST 4151-72 (1974). Drinking water. Method for determining the total stiffness, M., P. 6.

3. Dmitrieva E.A. (2004). Socio-ecological issues of water quality in water bodies - sources of drinking water supply, Municipal economy of cities: scientific-technical coll, Engineering, K., P. 50-59.

4. Kruglova A.A. (2009). Legal framework improvement for packaged mineral and drinking water, Abstract Thesis for a degree of Can. Tech. Sc., Lviv, P. 23.

5. Sydorenko O.V. (2015). Factors for quality formation of drinking water, Ukraine and the EU: overcoming technical barriers in trade (Kyiv, 18 - 19 March 2015): thesis reported, Kyiv National Trade \& Economic University, K., P. 261.

6. Shcherbak V.I. (2013) Estimation of potential and current threats to the ecological condition, water quality and diversity of various types of reservoirs and watercourses of metropolis, Integrated Management of Water Resources, K., P. 26-39.

7. World Health Organization (1997). Guidelines for drinking-water quality, Geneva, P. 5-7. 